\title{
Analisis Beberapa Parameter Kimia Dan Kandungan Logam Pada Sumber Air Tanah Di Sekitar Pemukiman Mahasiswa UIN Syarif Hidayatullah Jakarta
}

\author{
Hendrawati \\ Program Studi Kimia FST UIN Syarif Hidayatullah Jakarta \\ hendrageulis@yahoo.co.id
}

\begin{abstract}
Abstrak
Penelitian tentang "Analisis Beberapa Parameter Kimia dan Kandungan Logam Pada Sumber Air Tanah di Sekitar Pemukiman Mahasiswa UIN Syarif Hidayatullah Jakarta" telah dilakukan di Laboratorium Kimia dan Laboratorium Lingkungan UIN Syarif Hidayatullah Jakarta. Pengambilan sampel dilakukan dengan cara sampling purposif dengan memperhatikan pertimbangan kondisi serta keadaan dari daerah penelitian. Titik yang diambil sebanyak 12 titik dengan jarak antara satu titik dengan titik lain yang berdekatan yaitu $\pm 200 \mathrm{~m}$. Berdasarkan data yang diperoleh dari hasil analisa kualitas air tanah/sumur di daerah pemukiman mahasiswa sekitar kampus UIN Syarif Hidayatullah Jakarta maka dapat disimpulkan bahwa : 1) Untuk analisis parameter suhu berkisar antara $27,00-28,50^{\circ} \mathrm{C}$, dan berada dibawah standar baku mutu Depkes 2) Untuk analisis parameter $\mathrm{pH}$ berkisar antara 5,7 sampai 7,8; 3) Untuk analisis parameter kadar amoniak<0,01-0,34 mg/L, dan berada dibawah standar baku mutu Depkes 4) Untuk analisis parameter kadar klorida $22,33-64,7 \mathrm{mg} / \mathrm{L}$ dan berada dibawah standar baku mutu Depkes 5) Untuk analisis parameter kadar besi secara umum berada dibawah ambang batas kecuali lokasi 2 dan 3. Dari data yang diperoleh diharapkan menjadi informasi yang berharga bagi penduduk di sekitar lokasi penelitian. Terutama pada beberapa lokasi yang nilai parameternya melebihi standar baku mutu Depkes, untuk mengantisipasi tidak mengkonsumsi air sumber secara langsung, tapi harus mengalami serangkaian pengolahan terlebih dahulu.
\end{abstract}

Kata kunci : kualitas air, parameter kimia, kandungan logam

\begin{abstract}
Research about "analysis some chemical parameters in water around campus of Islamic Stated University Syarif Hidayatullah Jakarta" has been done. Sampling method is done by the way of sampling purposif, that is done by paying attention to consideration of condition of and situation from research area. Where point taken counted 12 point intervally 1 point with nearby other point that is $200 \mathrm{~m}$. Result of water quality analysis in water territory around Campus of Islamic Stated University Syarif Hidayatullah Jakarta , temperature ranges from $27-28,5^{\circ} \mathrm{C}$. Chemical parameter is obtained $\mathrm{pH}$ ranges from 5,7-7,8; Condition of water territory region around Campus of Islamic Stated University Syarif Hidayatullah Jakarta within measure enabled by government based on Kep02/MENKLH/1988 about standard quality of sea-water.
\end{abstract}

Key words : water quality, physics and chemical parameter

\section{PENDAHULUAN}

Air sangat penting bagi kehidupan, baik manusia, hewan maupun tumbuhan. Seluruh proses metabolisme dalam tubuh makhluk hidup berlangsung dalam media air. Air dalam kehidupan sehari-hari digunakan untuk berbagai keperluan seperti keperluan rumah tangga, pertanian, transportasi bahkan sampai industri.
Air sebagai pelarut universal, memiliki kemampuan untuk melarutkan berbagai zat, mulai fasa gas dari udara, fasa cair dari berbagai larutan, fasa padat dan juga mikroorganisme. Oleh karena itu air banyak sekali mengandung berbagai zat terlarut maupun tidak terlarut, sehingga air sangat sukar diperoleh dalam keadaan murni. Apabila kandungan berbagai zat tersebut tidak 
mengganggu kesehatan manusia, maka air dianggap bersih. Air dikatakan tercemar apabila terdapat gangguan terhadap kualitas air, dimana kandungan berbagai zat sudah melebihi ambang batas. Ambang batas kadar zat dalam air berbeda-beda untuk jenis air sesuai peruntukannya. Misalnya kadar zat untuk air minum berbeda ambang batasnya dengan kadar suatu zat untuk industri. Hal ini telah diatur oleh pemerintah atau pihak berwenang yang telah dibakukan dalam sebuah surat keputusan.

Secara geografis, kampus UIN Syarif Hidayatullah Jakarta terletak di daerah pemukiman padat penduduk. Hal ini tentu saja berdampak terhadap ketersediaan sumber air yang bersih. Penduduk/mahasiswa yang berada di lingkungan kampus umumnya menggunakan sumber air tanah/air sumur untuk keperluan sehari-hari. Oleh karena itu penelitian mengenai kualitas air tanah/air sumur di sekitar kampus menjadi hal yang menarik untuk dilakukan terutama bila dikaitkan dengan standar baku mutu air yang sesuai keputusan dengan keputusan Menteri Kesehatan Republik Indonesia.

\section{METODE PENELITIAN}

\section{Tempat dan Waktu Penelitian}

Penelitian ini meliputi dua kegiatan yaitu kegiatan di lapangan dan di laboratorium. Lokasi pengambilan sampel terletak di daerah pemukiman sekitar kampus UIN Syarif Hidayatullah Jakarta, yang digunakan sebagai lokasi penginapan Mahasiswa (Kost Mahasiswa). Analisis parameter kimia dilakukan di Laboratorium Kimia dan Laboratorium Lingkungan UIN Syarif Hidayatullah Jakarta dan dilaksanakan pada bulan April-Juni 2007.

\section{Alat dan Bahan}

Alat yang digunakan adalah Spektrofotometer Serapan Atom (AAS) Analis 700 Perkin Elmer, Spektrofotometer UV-Vis Winlab Perkin Elmer, botol BOD, erlenmeyer, $\mathrm{pH}$ meter, buret, labu ukur, gelas piala, termometer, pipet gondok, neraca analitik, hot plate, labu semprot, pipet tetes dan magnetik stirer.

Sampel air tanah (air sumur) diambil di sekitar pemukiman/kost mahasiswa, buffer $\mathrm{pH}$ 4, 7 dan 10 untuk standarisasi $\mathrm{pH}$ meter, $\mathrm{H}_{2} \mathrm{O}_{2}$ $30 \% \mathrm{NaOH}$ dan pereaksi Nessler untuk analisa ammonia, $\mathrm{H}_{2} \mathrm{SO}_{4} \quad \& \quad \mathrm{HNO}_{3}$ untuk destruksi logam, sedangkan penetapan kadar klorida dilakukan dengan metode titrasi argentometri $\left(\mathrm{AgNO}_{3}\right)$

\section{Prosedur Sampling}

Dalam penelitian ini, titik pengambilan sampel ditetapkan berdasarkan lokasi pemukiman yang mengelilingi kampus I UIN Syarif Hidayatullah Jakarta..

Metode pengambilan sampel dilakukan dengan cara sampling purposif, yaitu dilakukan dengan memperhatikan pertimbangan kondisi serta keadaan dari daerah penelitian, dimana titik yang diambil sebanyak 10 titik dengan jarak antara 1 titik dengan titik lain yang berdekatan yaitu $200 \mathrm{~m}$.

Tabel 1. Parameter yang diukur

\begin{tabular}{|c|l|l|}
\hline No & Parameter yang diukur & \multicolumn{1}{|c|}{ Metode Acuan } \\
\hline 1 & Suhu & SNI \\
\hline 2 & pH & SNI \\
\hline 3 & Amonia & SNI \\
\hline 4 & Klorida & SNI \\
\hline 5 & Besi $(\mathrm{Fe})$ & SNI \\
\hline
\end{tabular}

\section{HASIL DAN PEMBAHASAN}

Pada Tabel 2 dicantumkan data-data hasil pengukuran pada setiap lokasi.

Tabel 2. Hasil Pengukuran Kualitas Air

\begin{tabular}{|c|c|c|c|c|c|c|}
\hline \multirow{2}{*}{$\begin{array}{c}\text { KOKE } \\
\text { LOKASI }\end{array}$} & \multicolumn{2}{|c|}{ Suhu $\left({ }^{\circ} \mathbf{C}\right)$} & \multirow{2}{*}{$\mathbf{p H}$} & $\begin{array}{c}\mathbf{N H}_{3} \\
(\mathbf{p p m})\end{array}$ & $\begin{array}{c}\text { Klorida } \\
(\mathbf{p p m})\end{array}$ & $\begin{array}{c}\text { besi } \\
(\mathbf{p p m})\end{array}$ \\
\cline { 2 - 6 } & $\mathbf{1}$ & $\mathbf{2}$ & & & & \\
\hline 1 & 27.00 & 27.00 & 7.46 & 0.02 & 33.30 & $<0.05$ \\
\hline 2 & 27.50 & 27.50 & 7.80 & 0.21 & 29.60 & 2.50 \\
\hline 3 & 28.00 & 27.50 & 5.80 & $<0.1$ & 36.90 & 0.42 \\
\hline 4 & 28.50 & 27.00 & 6.10 & 0.01 & 22.20 & $<0.05$ \\
\hline 5 & 28.00 & 27.00 & 5.70 & $<0.1$ & 40.70 & $<0.05$ \\
\hline 6 & 28.00 & 27.00 & 6.50 & 0.21 & 32.60 & $<0.05$ \\
\hline 7 & 27.00 & 27.50 & 7.00 & 0.16 & 27.10 & $<0.05$ \\
\hline 8 & 27.00 & 27.50 & 7.00 & 0.34 & 34.50 & $<0.05$ \\
\hline 9 & 27.00 & 27.00 & 6.60 & 0.24 & 51.70 & $<0.05$ \\
\hline 10 & 28.00 & 27.00 & 6.60 & 0.02 & 64.70 & $<0.05$ \\
\hline 11 & 28.00 & 27.00 & 6.00 & 0.03 & 36.90 & $<0.05$ \\
\hline 12 & 28.00 & 27.00 & 5.90 & 0.04 & 38.20 & $<0.05$ \\
\hline
\end{tabular}

\section{Analisis Suhu}

Gambar 1 menunjukkan hubungan lokasi pengambilan sample terhadap parameter suhu yang dilakukan saat pengambilan sample di lokasi (pengukuran 1) dan pada saat pengukuran di laboratorium (pengukuran 2). 


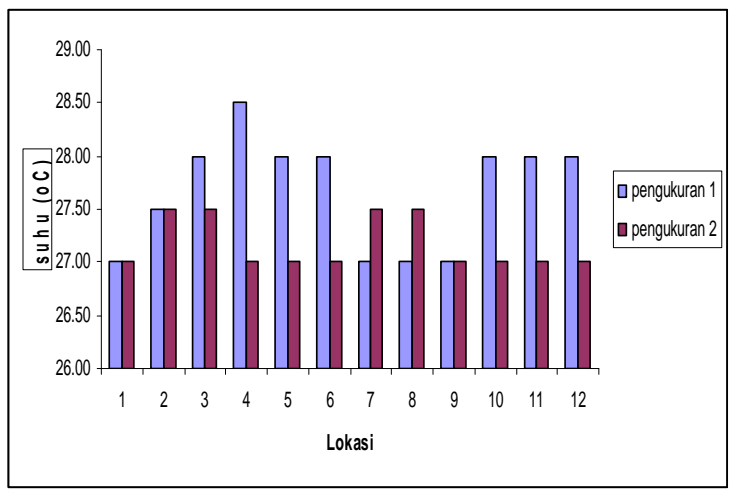

Gambar 1. Grafik hubungan lokasi pengambilan sampel terhadap parameter suhu

Berdasarkan grafik tersebut terlihat bahwa nilai suhu dari masing-masing lokasi bervariasi. Pengukuran I (saat pengambilan sampel di lokasi), nilai suhu berkisar 27,00$28,50^{\circ} \mathrm{C}$. Sedangkan untuk pengambilan II (saat pengukuran di laboratorium) adalah 27,00$27,50^{\circ} \mathrm{C}$. Pengukuran I, Nilai suhu bervariasi, hal tersebut terjadi karena pada saat pengambilan sampel, cuaca tidak dapat dipastikan (kadang-kadang cerah, kadangkadang mendung). Sedangkan jarak waktu pengambilan sampel dari satu lokasi ke lokasi berikutnya dapat mencapai 15 sampai 30 menit, sehingga dapat memungkinkan terjadinya perubahan cuaca dan mengakibatkan suhu terkadang naik dan terkadang turun. Pengukuran 2, nilai suhu cenderung konstan, hal ini disebabkan tempat dan waktu pengukuran hampir serentak pada tempat yang sama.

Pengaruh suhu tidak begitu besar terhadap tingkat pencemaran, penggunaan sumber air untuk dikonsumsi, untuk mandi./mencuci ataupun untuk keperluan lainnya. Biasanya penduduk/mahasiswa mengolah air sumber terlebih dahulu (dimasak), jika akan dikonsumsi. Tetapi untuk kepentingan analisis di laboratorium (pengukuran 2), kondisi suhu air sumber, diperlukan keseragaman. Sehingga dibuat kondisi yang sama.

Berdasarkan Keputusan Menteri Kesehatan Republik Indonesia Nomor 907/Menkes/SK/VII/2002 Tentang syarat-syarat dan pengawasan kualitas air minum, menyatakan bahwa suhu air yang layak untuk dikonsumsi adalah suhu udara $\pm 3^{\circ} \mathrm{C}$, maksudnya adalah suhu air harus lebih besar dari suhu udara sekitar $1-3{ }^{\circ} \mathrm{C}$. Suhu udara air sampel yang diuji sekitar $27-28{ }^{\circ} \mathrm{C}$, sedangkan suhu udara saat pengukuran sekitar $25-26{ }^{\circ} \mathrm{C}$.
Nilai suhu tersebut, sesuai dengan standar baku mutu Menteri Kesehatan.

\section{Analisis pH}

Gambar 2 menunjukkan hubungan antara lokasi pengambilan sample terhadap parameter $\mathrm{pH}$ yang dilakukan segera saat sample air diambil. Pengukuran di lakukan di laboratorium menggunakan $\mathrm{pH}$ meter.

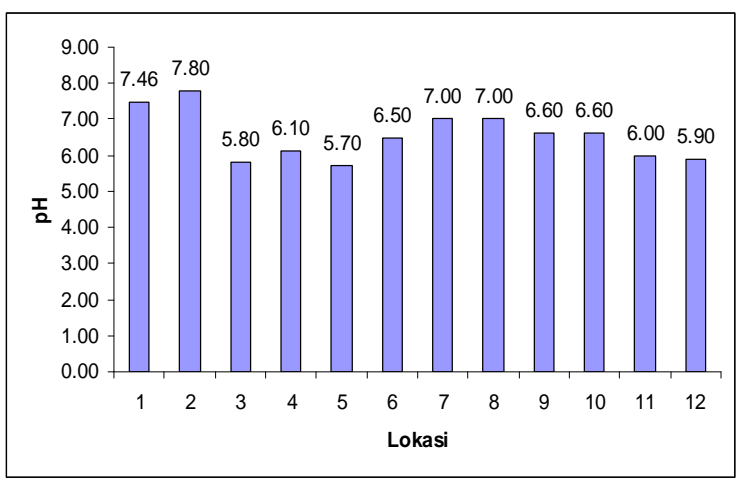

Gambar 2. Grafik hubungan lokasi pengambilan sampel terhadap parameter $\mathrm{pH}$

Nilai $\mathrm{pH}$ air sampel bervariasi berkisar antara 5,7 sampai 7,8. Berdasarkan Keputusan Menteri Kesehatan Republik Indonesia Nomor 907/Menkes/SK/VII/2002 Tentang syaratsyarat dan pengawasan kualitas air minum, menyatakan bahwa $\mathrm{pH}$ air yang layak untuk dikonsumsi adalah sekitar $\mathrm{pH}$ 6,5-8,5. Lokasi 1,2,6,7,8,9, dan 10, memiliki nilai $\mathrm{pH}$ 6,6-7,8. Nilai ini masih berada di dalam range yang diputuskan Menteri Kesehatan. Jadi dari nilai $\mathrm{pH}$, air sumber dari lokasi tersebut layak untuk dikonsumsi. Lokasi 3,4,5,11 dan 12, pH kurang dari 6,5. Nilai ini lebih rendah dari standar baku mutu Menteri Kesehatan, sehingga dari nilai $\mathrm{pH}$, air sumber dari lokasi ini tidak layak untuk dikonsumsi. Berdasarkan Uji $\mathrm{pH}$ sebelumnya, yang sering dilakukan pada saat praktikum di laboratorium, secara umum $\mathrm{pH}$ air sampel di dalam kampus UIN Syarif Hidayatullah Jakarta memang bersifat sedikit asam, dengan nilai $\mathrm{pH}$ 6,00-7,30 (Hendrawati,2006). Nilai $\mathrm{pH}$ yang sedikit asam ini bisa disebabkan jenis tanah dan batuan di lokasi banyak mengandung kapur dan batuan karbonat, sehingga akan menyebabkan terbentuknya asam karbonat sehingga $\mathrm{pH}$ tanah dan air sumber bersifat asam.

\section{Analisis Amoniak}

Berdasarkan hasil pengujian kadar 
senyawa amoniak di sekitar Kampus UIN Syarif Hidayatullah Jakarta, didapatkan sebagian besar berada pada kisaran 0,1-0,34 $\mathrm{mg} / \mathrm{L}$ (Gambar 3). Sedangkan lokasi 3 dan lokasi 5 kadar amoniaknya $<0,01 \mathrm{mg} / \mathrm{L}$. Nilainilai ini masih dibawah ambang batas Standar Baku Mutu yang ditetapkan oleh Departemen Kesehatan, yaitu sebesar 1,5mg/L.

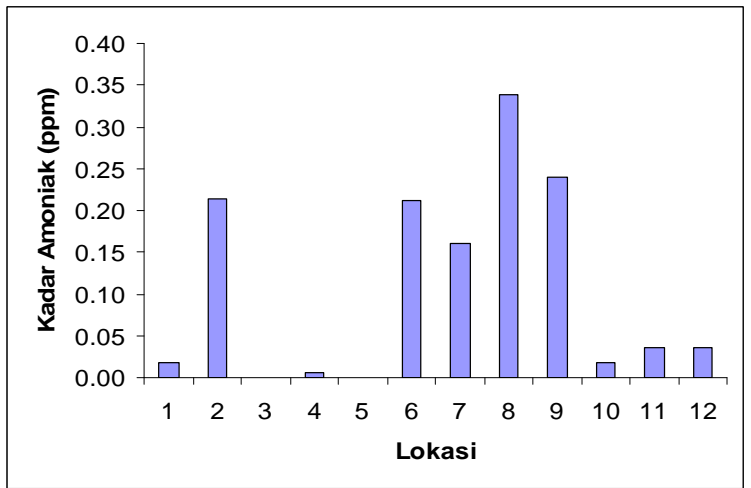

Gambar 3. Grafik hubungan lokasi pengambilan sampel terhadap parameter Kadar Amoniak

Berdasarkan standar baku mutu Departemen Kesehatan tersebut, maka air tanah dari semua lokasi pengambilan sampel mempunyai kadar amoniak yang rendah, sehingga layak dikonsumsi.

\section{Kadar Klorida}

Pengukuran kadar klorida pada sampel air menggunakan metode argentometri, yaitu titrasi menggunakan larutan $\mathrm{AgNO}_{3}$ sebagai titrant. Pada metode ini, sampel terlebih dahulu dikondisikan suasana netral dengan cara menambahkan asam sulfat dan natrium hidroksida, hal ini disebabkan karena metode argentometri merupakan metode Mohr yang bereaksi dalam keadaan netral. Sampel kemudian ditambahkan larutan hidroksida yang bertujuan untuk menghilangkan pengotor selain klorida.

Data nilai kadar klorida pada masingmasing lokasi dapat dilihat pada gambar 4 . Hasil pengukuran kadar klorida pada air tanah di lokasi pengambilan sampel antara 22,3364,7mg/L. Nilai ini masih berada dibawah ambang batas Standar Baku Mutu Departemen Kesehatan, yaitu 250mg/L. Sehngga jika dilihat dari kadar kloridanya, semua air tanah di semua lokasi pengambilan sampel layak untuk dikonsumsi.

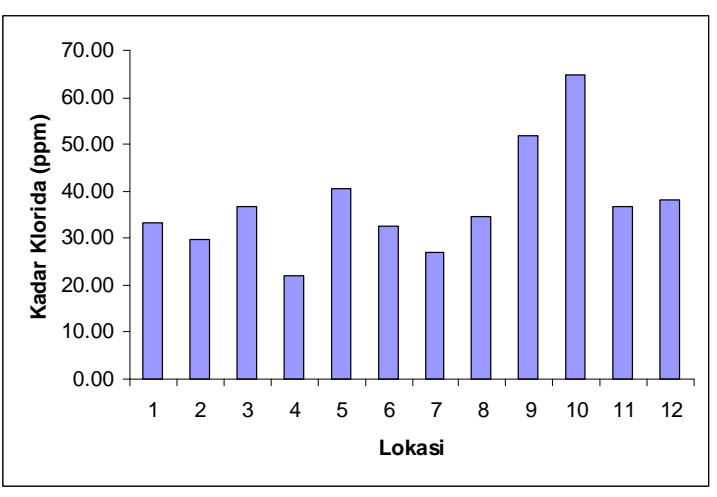

Gambar 4. Grafik hubungan lokasi pengambilan sampel terhadap parameter kadar klorida

\section{Kadar Besi}

Penentuan kadar logam berat dalam hal ini kadar besi $(\mathrm{Fe})$ dalam sample air tanah/air sumur dapat dilakukan dengan menggunakan instrument Spektrofotometrik Serapan Atom (SSA) yang didasarkan pada Hukum LambertBeer, yaitu banyaknya sinar yang diserap berbanding lurus dengan konsentrasi zat.

Apabila kadar besi dalam sample melebihi ambang batas yang telah ditentukan oleh dinas kesehatan, maka air tersebut dinyatakan telah tercemar. Berdasarkan Surat Keputusan Menteri Kesehatan Republik Indonesia No. 907/Menkes/SK/VII/2002, kadar besi yang diperbolehkan adalah $0,3 \mathrm{mg} / \mathrm{L}$.

Tabel 3. Data hasil pengukuran kadar besi

\begin{tabular}{|c|c|}
\hline Kode Lokasi & Kadar besi $(\mathrm{mg} / \mathrm{L})$ \\
\hline 1 & $<0.05$ \\
\hline 2 & 2,50 \\
\hline 3 & 0,42 \\
\hline 4 & $<0.05$ \\
\hline 5 & $<0.05$ \\
\hline 6 & $<0.05$ \\
\hline 7 & $<0.05$ \\
\hline 8 & $<0.05$ \\
\hline 9 & $<0.05$ \\
\hline 10 & $<0.05$ \\
\hline 11 & $<0.05$ \\
\hline 12 & $<0.05$ \\
\hline
\end{tabular}

Dari tabel di atas terlihat nilai kadar besi pada lokasi 2 dan 3 masing-masing 2,50ppm dan 0,42ppm. Nilai ini lebih tinggi dari $0,3 \mathrm{mg} / \mathrm{L}$, sehingga berdasarkan parameter kadar besi, air dari lokasi 2 dan 3 ini tidak layak untuk dikonsumsi. Sedangkan air sumber dari lokasi lainnya kurang dari $0,05 \mathrm{ppm}$. Nilai ini 
lebih rendah dari baku mutu yang ditetapkan oleh departemen kesehatan, sehingga dari parameter kadar besi, air sumber dari lokasi tersebut layak untuk dikonsumsi.

\section{KESIMPULAN}

Berdasarkan data yang diperoleh dari hasil analisa kualitas air tanah/sumur di daerah pemukiman mahasiswa sekitar kampus UIN Syarif Hidayatullah Jakarta dapat disimpulkan bahwa hasil analisis parameter suhu berkisar antara $27,00-28,50^{\circ} \mathrm{C}, \mathrm{pH}$ berkisar antara 5,7 sampai 7,8; amoniak antara $0,01-0,34 \mathrm{mg} / \mathrm{L}$, sedangkan untuk klorida 22,33-64,7mg/L. Untuk analisis parameter kadar besi secara umum berada dibawah ambang batas kecuali pada lokasi 2 dan 3. Dari hasil analisa tersebut diharapkan dapat menjadi informasi yang berharga bagi penduduk di sekitar lokasi penelitian, terutama pada beberapa lokasi yang nilai parameternya melebihi standar baku mutu Depkes, untuk mengantisipasi tidak mengkonsumsi air sumber secara langsung, tapi harus mengalami serangkaian pengolahan terlebih dahulu.

\section{DAFTAR PUSTAKA}

1. Achmad, Rukesih. 2004.Kimia Lingkungan. Yogyakarta, Andi Yogyakarta.

2. Asbar, Konsep Bioegion Dalam Pengelolaan Wilayah Pesisir : Suatu Tinjauan Filosofi. Makalah Falsafah Sains, Program Pasca Sarjana/S3, IPB, 2002.

3. Day R. A., JR and A. L. Underwood, Analisis Kimia Kuantitaif, ed 5, Erlangga, Jakarta, 1990.

4. Keputusan Menteri Kesehatan Republik Indonesia 907/Menkes/SK/VII/2002. Tentang Estándar Baku Mutu Air Minum.

5. Khopkar S. M., Konsep Dasar Kimia Analitik, UI Press, Jakarta, 1990.

6. Periodic Table, Los Alamos National Laboratory,2003.

www.pearl1.lanl.gov/periodic/elements.htm 1 .

7. Vogel, A.I., A Text Book of Quantitative Inorganic Analysis, $3^{\text {rd }}$ ed. 